\title{
The Changes in Goat Milk during Heating and Storage after Milking
}

\author{
Damla Yanmış ${ }^{*}$, Hayri Coşkun \\ Department of Food Engineering, Abant Izzet Baysal University, Bolu, Turkey \\ *Corresponding author: damlayanmis@hotmail.com
}

Received November 12, 2018; Revised December 16, 2018; Accepted December 25, 2018

\begin{abstract}
In this study, it was aimed to investigate the changes in goat milk after heating at different temperatures and during storage in different packaging materials. For this purpose, milks obtained from a farm producing goat milk in Bolu in Turkey were divided into two groups, the first group was pasteurized at $65^{\circ} \mathrm{C}$ for $30 \mathrm{~min}$ and the second group at $95^{\circ} \mathrm{C}$ for $5 \mathrm{~min}$. Each group of pasteurized milk samples was again divided into two groups and filled into transparent and brown bottles. Samples were taken before and after heat treatments to reveal the effect of heating, and also on $0^{\text {th }}, 5^{\text {th }}$ and $10^{\text {th }}$ days of storage period $\left(a t+4^{\circ} \mathrm{C}\right)$ to determine storage effect. The results showed that heat treatment caused increases in dry matter values of goat milk samples $(P<0.05)$. On the contrast, heat treatment had no effect on the values of fat, acidity, viscosity and vitamins significantly $(P>0.05)$. Heating the milk samples by High Pasteurization method resulted with significantly high values of sedimentation. Besides hydroxymethylfurfural, nonenzymatic browning compounds and $\mathrm{L}^{*}$ values increased as the heating value increased. The acidity values of the samples increased during storage $(P<0.05)$. The hydroxymethylfurfural and nonenzymatic browning compounds values of the Low Pasteurized and High Pasteurized milk samples were differed from each other $(P<0.05)$ while the packaging materials and the storage time were had no significant effect $(P>0.05)$. Also, sedimentation and $\mathrm{L}^{*}$ values were affected during storage $(P<0.05)$.
\end{abstract}

Keywords: goat milk, heating, storage

Cite This Article: Damla Yanmış, and Hayri Coşkun, "The Changes in Goat Milk during Heating and Storage after Milking." Journal of Food and Nutrition Research, vol. 6, no. 12 (2018): 760-766. doi: $10.12691 /$ fnr-6-12-6.

\section{Introduction}

Goat milk has important nutritional value and economic benefits in many parts of the world due to its composition [1]. The basic composition of goat milk resembles that of cows; both milk types have high protein, ash and low lactose content. However, it is known that products made with goat milk have some properties that provide technological advantages such as a smoother texture, lower amount of $\alpha$-casein, smoother gel products, higher water retention capacity and lower viscosity compared to cow milk [2]. In addition, there are also fundamental differences in the structure, composition and size of casein micelle, the proportion of individual protein fractions, the higher non-protein nitrogen and mineral compounds in goat's milk $[3,4]$.

Microbial contamination after milking causes deterioration easily and rapidly because of rich nutrient content of the milk. The most common method applied for deactivation of microorganisms is heat treatment. [5] However, the temperature degree and time combination applied are of great importance. Otherwise, beside of health concern some undesirable changes such as loss of nutritional value, color, taste and flavor may occur $[1,5,6,7]$.
Similarly, in the storage process, many degradation may occur due to internal effects such as protease, lipase, or from external sources like processing, storage conditions, temperature, exposure to light and contamination with metal or microorganisms [8]. While indigenous lipases and proteases of milk are inactivated by pasteurization, the enzymes released from microorganisms after contamination or during cold storage of milk can not be completely inactivated at HTST pasteurization and not even at UHT sterilization [5]. With effective packaging, it is possible to protect milk against external influences such as microbial contamination, light and oxygen, and thus undesirable flavor development and nutrient losses originating from lipid and protein oxidations can be largely avoided [9].

The studies on different heat treatment norms applied to cow and sheep milk and storage in different packaging materials have been frequently encountered in the literature. Reference [10] reported that pasteurization and boiling had no effect on the values of fat, protein, lactose, ash, non-fat dry matter and total dry matter. Review of the literature showed that the studies mostly focused on the effects of heat treatment especially on milk vitamins and the changes during storage [11-28]. In addition, there are many studies on hydroxymethylfurfural (HMF) and nonenzymatic browning compounds (NEBC) formed by heat 
treatment [29,30,31]. However, the number of studies related with the effects of heating and storage on goat milk is limited.

Nowadays, there is an increasing interest in goat milk both in our country and in the world, resulting with increasing the production of goat's milk and its products. Therefore, more information is needed on production and processing of goat milk. In this study, it was aimed to reveal the changes in goat milk caused by heating at different temperatures and times, and also by the storage at $+4{ }^{\circ} \mathrm{C}$ in different packing materials for ten days. The results are important for the processing of goat milk and for the future studies.

\section{Materials and Methods}

The goat milk used in the study was taken from a local goat (Saanen race) milk producer in Bolu in Turkey at the beginning of the lactation period (April 2017). The filtration, pasteurization, storage processes of the goat milk were carried out at the dairy technology laboratory of Department of Food Engineering, Bolu Abant İzzet Baysal University, Turkey. First, 34 L of goat milk was taken and divided into three groups. The first $15 \mathrm{~L}$ portion of the milk was pasteurized at $65 \pm 2{ }^{\circ} \mathrm{C}$ for 30 minutes (LP) and the second $15 \mathrm{~L}$ portion was pasteurized at $95 \pm 1{ }^{\circ} \mathrm{C}$ for 5 minutes (HT). The remaining $4 \mathrm{~L}$ of milk was not pasteurized and used for the analyses of raw milk. Each pasteurized goat milk group was then filled into transparent and amber colored glass bottles, intending whether or not the light expose during daily and routine process have any effect on milk properties. All milk bottles were placed in a refrigerator at $+4{ }^{\circ} \mathrm{C}$ and stored for ten days. Production was repeated twice. Physical, chemical and biochemical analyses were carried out by taking samples from the milk after heat treatments and on days 0,5 and 10 of storage time.

\subsection{Chemical, Biochemical and Color Analysis}

In goat milk samples, dry matter, fat, protein and acidity values were determined by the methods of Metin [32].

Color values of goat milk samples were determined using Hunter Lab chroma meter (Hunter, LabColorFlex A60, USA); The viscosity values were measured with a viscometer (AND vibro viscometer SV-10, Japan) $\left(+4^{\circ} \mathrm{C}\right)$. Sedimentation values of milk samples were determined according to Katsiari et al. [33].

Hydroxymethylfurfural content (HMF) of the milk samples was found by the method of Keeney and Bassette (1958). Nonenzymatic brown colored compounds (NEBC) were determined as described by Guingamp et al. [34].

\subsubsection{Determination of Vitamin E}

About $1 \mathrm{~g}$ of homogenized sample was weighed in a plastic tube with a lid. $200 \mu \mathrm{l}$ of methanolic pyrocatechol $(0.2 \mathrm{~g} / \mathrm{ml})$ and $5 \mathrm{ml} 1 \mathrm{M} \mathrm{KOH}$ were added to the sample. The mixture was vortexed for $20 \mathrm{~s}$, saponified for $10 \mathrm{~min}$ in the presence of ultrasound and vortexed again for 20 seconds. Then $5 \mathrm{ml}$ of hexane and $1 \mathrm{ml}$ of distilled water were added to the mixture and it was again vortexed for 1 minute. Subsequently $3 \mathrm{ml}$ from the upper hexane layer were taken and evaporated until dry, using a Büchi rotovapor R-215 rotary evaporator (Büchi Labortechnik $\mathrm{GmbH}$, Essen, Germany). The residue was dissolved in $0.5 \mathrm{ml}$ of methanol and an aliquot was transferred through a nylon filter into $1 \mathrm{ml}$ Eppendorf tube, which was placed in the freezer $\left(-20^{\circ} \mathrm{C}\right)$ for 30 minutes. The sample was centrifuged for 2 min (Eppendorf mini spin plus microcentrifuge, by $14.4 \mathrm{rpm}$ ) and drained off into a dark vial. The analysis was carried out using an Ultimate 3000 High Performance Liquid Chromatograph (Thermo Fisher Scientific, Dionex, Sunnyvale, USA) with a quaternary pump, refrigerated autosampler, column heater and FLD and DAD detectors. Tocols and tocopherols in the sample were determined by HPLC-FLD under the following conditions: analytical column Develosil $5 \mu \mathrm{m}$ RP AQUEOUS $(250 \times 4.6 \mathrm{~mm})$ (Phenomenex, Torrance, USA); precolumn Develosil $5 \mu \mathrm{m} \mathrm{C30} \mathrm{UG-100A}(10 \times 4 \mathrm{~mm})$ (Phenomenex, Torrance, USA); mobile phase methanol: deionised water $(93: 3, \mathrm{v} / \mathrm{v})$, HPLC super gradient methanol (Lach-Ner, Neratovice, Czech Republic) and Milli-Q water, isocratic elution; flow rate $1 \mathrm{ml} / \mathrm{min}$; injection $10 \mu \mathrm{l}$, column temperature $30{ }^{\circ} \mathrm{C}$; detection FLD (excitation 292 $\mathrm{nm}$, emission $330 \mathrm{~nm}$ ). Retinol was determined under the same chromatographic conditions using DAD detector $(\lambda=325 \mathrm{~nm})$. The detection limits for tocopherol $(\mathrm{T})$, expressed as a ratio of three times the value of the signal-to-noise ratio. All results were expressed in $\mathrm{mg} / \mathrm{L}$ of milk as the mean value of three replications [35]. All procedures were done at the research centre of YENIGIDAM at Bolu Abant Izzet Baysal University.

\subsubsection{Determination of Vitamin $B_{1}$ and $B_{2}$}

The analyses of these vitamins were also done at the research center of YENIGIDAM of Bolu Abant Izzet Baysal University, according to the method given by Albala-Hurtado et al. [36]. For the analysis, $10.5 \mathrm{~g}$ of sample were accurately weighed into a $50 \mathrm{ml}$ centrifuge tube (30 mm diameter). Then, $1 \mathrm{~g}$ TCA solid and a magnetic stirring bar were added. The mixture was thoroughly shaken for 10 min over a magnetic stirring plate and centrifuged at $1250 \mathrm{xg}$ to separate the two phases for $10 \mathrm{~min}$. After, $3 \mathrm{ml} 4 \%$ TCA were added to the solid residue, it was mixed thoroughly for $10 \mathrm{~min}$, and centrifuged. Then, solid-phase was discarded. The two acid extracts were combined in a $10 \mathrm{ml}$ volumetric flask and the volume was filled with $4 \%$ TCA. Samples were always protected from light by covering tubes and flasks with aluminum foil and working under subdued lighting conditions. The HPLC system (Hewlett-Packard, CA, USA) consisted of an HP 1050 system controller pump, an HP 1050 Series degassing device, an HP 1100 autosampler with $20 \mu \mathrm{L}$ fixed loop injector, and an HP 1050 Series UV detector. Data collection was accomplished by a Chemstation system HP 3365-11. Stock solutions: $100 \mathrm{mg} / \mathrm{l}$ of riboflavin in $2.4 \%(\mathrm{v} / \mathrm{v})$ aqueous acetic acid; $1000 \mathrm{mg} / \mathrm{l}$ of nicotinamide, pyridoxal, pyridoxine, pyridoxamine, thiamine, and cyanocobalamin in $2.4 \%(\mathrm{v} / \mathrm{v})$ aqueous acetic acid. Intermediate solutions: $10 \mathrm{mg} / 1$ of riboflavin in aqueous acetic acid, and $50 \mathrm{mg} / \mathrm{l}$ of the rest of vitamins in aqueous acetic acid. Working solutions: 0.05, 0.1, 0.5, $0.8,1,1.5,2,3$ and $5 \mathrm{mg} / 1$ for the analytes, all of them in $2.4 \%$ aqueous acetic acid. All standard solutions were 
filtered through a $0.45 \mu \mathrm{m}$ membrane (Millipore), protected from light, and stored at $4{ }^{\circ} \mathrm{C}$. The mobile phase contained $5 \mathrm{mM}$ octanesulfonic acid, $0.5 \%$ triethylamine, $2.4 \%$ glacial acetic acid, and $15 \%$ of methanol. The separation was performed on a Tracer Spherisorb ODS 2 C18 column 250X4.6 mm, 5 Ixm (Teknokroma, Barcelona, Spain), with a matching guard cartridge. Analyses were carried out isocratically at room temperature at a flow-rate of $1 \mathrm{ml} / \mathrm{min}$.

\subsection{Statistical Analysis}

Variance analysis and the "Tukey Multiple Comparison" test was used to determine the differences between the groups. Minitab (version 16.0) package program was used for performing statistical analysis.

\section{Results and Discussion}

\subsection{The Effect of Heating on Some Characteristics of Goat's Milk}

Table 1 shows the physical, chemical and biochemical properties of raw and the heat-treated goat milk samples. According to the Table, the value of dry matter was found to be slightly higher in heat-treated milk samples $(\mathrm{P}<0.05)$. The reason for this might be due to water loss during the heating process of the milk.

On the other hand, there was no change in protein and fat values in raw and heat-treated milk samples $(\mathrm{P}>0.05)$. Similar results were reported by Khan et al. [10].

Due to the effect of heating, the acidity of goat milk samples were changed slightly, but not significant $(\mathrm{P}>0.05)$. As a result of heating the milk, additional acidity principally formic and acetic acid may develop.

The amount of sedimentation in goat milk samples was higher in HP samples $(\mathrm{P}<0.05)$. This result may be due to destabilization of casein particles [37,38]. Similar results were reportant by Yaman and Coşkun [38].

As seen from Table 1, the viscosity values of the heat-treated samples were found lower (the lowest in HP samples) than those of raw milk, but this was statistically insignificant $(\mathrm{P}>0.05)$. The viscosity value of the raw goat milk was measured to be $2.49 \mathrm{mPa}$.s by El-Hatmi et al. [39] while Yaman and Coşkun [38] found viscosity value as $2.77 \mathrm{mPa}$.s for pasteurized goat milk samples. It could be said that as the heating degree increases, the collection of caseins and the formation of aggregates may cause a decrease in the viscosity values of the samples. In addition, the viscosity value may be affected by differences in the milk components such as protein and fat due to factors such as animal feeding, lactation period, etc. [40].

The L* (lightness-darkness) value of the samples increased as the increase in degree of heating, and the increase was significant $(\mathrm{P}<0.05)$ in the HP samples compared to the raw milk samples. On the other hand, the $a^{*}$ values (green-red) of the LP and HP samples were lower than that of raw milk samples $(P<0.05)$. Similarly, $b^{*}$ values of the heated milk samples were lower, but insignificant $(\mathrm{P}>0.05)$. The $\mathrm{L}^{*}, \mathrm{a}^{*}, \mathrm{~b}^{*}$ values obtained are lower than the results of Yaman and Coşkun [38], and similar to those given by Güler and Park [41]; may be due to the feeding of the animal, the composition of the milk, or the different heating parameters applied. It is known that vitamin A ( $\mathrm{L}$ value), $\beta$ carotene (b value) and their conversion rate to each other in the composition of the milk directly affect the color of the milk, and also the heat treatment applied to the milk increases the caramelization and browning reactions as the heating intensity increases, resulting with browning in the milk color [40]. In addition, the degradation of vitamin A giving white color of the milk may increase darkness slightly in color of milk [42].

As it can be monitored from Table 1, hydroxy methyl furfural (HMF) values increased as increase in heating temperature and time. When compared to the raw goat milk samples, the LP and HP samples had higher HMF values $(\mathrm{P}<0.05)$. Similar results were also found by Schamberger and Labuza [31] and Güneşer et al. [29]. The values of non-enzymatic browning compounds (NEBC) were found higher in LP and HP samples than those of raw milk samples, but only HP value was significantly different from $\mathrm{R}$ samples $(\mathrm{P}<0.05)$. Results obtained in our study are similar to those obtained by Guingamp et al. [34].

Table 1. The Effect of Heating on Some Chemical, Physical and Biochemical Properties of Goat Milk Samples $(\bar{x} \pm$ SD, $n=2)$

\begin{tabular}{|c|c|c|c|}
\hline Properties & $\mathrm{R}$ & LP & $\mathrm{HP}$ \\
\hline Dry matter $(\%)$ & $12.11 \pm 0.024^{\mathrm{b}^{*}}$ & $12.28 \pm 0.011^{\mathrm{a}}$ & $12.24 \pm 0.027^{\mathrm{a}}$ \\
\hline Protein $(\%)$ & $3.11 \pm 0.170^{\mathrm{a}}$ & $3.29 \pm 0.071^{\mathrm{a}}$ & $3.15 \pm 0.099^{\mathrm{a}}$ \\
\hline Fat (\%) & $3.80 \pm 0.000^{\mathrm{a}}$ & $3.75 \pm 0.071^{\mathrm{a}}$ & $3.75 \pm 0.071^{\mathrm{a}}$ \\
\hline Acidity (Lactic Acid, \%) & $0.14 \pm 0.001^{\mathrm{a}}$ & $0.13 \pm 0.004^{\mathrm{a}}$ & $0.13 \pm 0.001^{\mathrm{a}}$ \\
\hline Sedimentation (g dry weight $/ 40 \mathrm{~mL}$ ) & $0.043 \pm 0.001^{\mathrm{ab}}$ & $0.042 \pm 0.000^{\mathrm{b}}$ & $0.050 \pm 0.003^{\mathrm{a}}$ \\
\hline Viscosity (mPa.s) & $2.67 \pm 0.099^{\mathrm{a}}$ & $2.52 \pm 0.141^{\mathrm{a}}$ & $2.49 \pm 0.099^{\mathrm{a}}$ \\
\hline \multirow{3}{*}{ Color $\left(\mathrm{L}^{*}, \mathrm{a}^{*}, \mathrm{~b}^{*}\right.$ respectively) } & $81.323 \pm 0.304^{\mathrm{b}}$ & $82.055 \pm 0.226^{\mathrm{ab}}$ & $82.858 \pm 0.219^{\mathrm{a}}$ \\
\hline & $-2.958 \pm 0.032^{\mathrm{a}}$ & $-3.415 \pm 0.079^{\mathrm{b}}$ & $-3.318 \pm 0.034^{\mathrm{b}}$ \\
\hline & $5.983 \pm 0.465^{\mathrm{a}}$ & $5.964 \pm 0.459^{\mathrm{a}}$ & $5.930 \pm 0.485^{\mathrm{a}}$ \\
\hline $\mathrm{HMF}(\mu \mathrm{mol} / \mathrm{L})$ & $0.026 \pm 0.004^{\mathrm{a}}$ & $0.030 \pm 0.004^{\mathrm{b}}$ & $0.052 \pm 0.003^{\mathrm{b}}$ \\
\hline $\operatorname{NEBC}\left(\mathrm{A}_{340}\right)$ & $0.095 \pm 0.020^{\mathrm{b}}$ & $0.110 \pm 0.017^{\mathrm{ab}}$ & $0.175 \pm 0.010^{\mathrm{a}}$ \\
\hline$\alpha$-tocopherolequivalent (TE) (mg/L) & $0.30 \pm 0.028^{\mathrm{a}}$ & $0.32 \pm 0.035^{\mathrm{a}}$ & $0.32 \pm 0.028^{\mathrm{a}}$ \\
\hline Vitamin $B_{1}(\mathrm{mg} / \mathrm{L})$ & $1.76 \pm 0.007^{\mathrm{a}}$ & $1.74 \pm 1.230^{\mathrm{a}}$ & $1.74 \pm 1.230^{\mathrm{a}}$ \\
\hline Vitamin $B_{2}(\mathrm{mg} / \mathrm{L})$ & $0.99 \pm 0.000^{\mathrm{a}}$ & $1.17 \pm 0.010^{\mathrm{a}}$ & $1.07 \pm 0.085^{\mathrm{a}}$ \\
\hline
\end{tabular}

R: Raw milk, LP: pasteurized milk at $65^{\circ} \mathrm{C}$ for 30 minutes, HP: pasteurized milk at $95^{\circ} \mathrm{C}$ for 5 minutes, n: number of samples analyzed, SD: standard deviation, HMF: hydroxy methyl furfural, NEBC: nonenzymatic browning compound, $\mathrm{L}^{*}$ : lightness $\left(0=\right.$ black, $100=$ white); $\mathrm{a}^{*}$ : green $(-)$ or red $(+)$; $\mathrm{b}^{*}$ : blue (-) or yellow (+), *: the means in each row carrying different letters statistically differ from each other $(\mathrm{P}<0.05)$, all others not $(P>0.05)$. 
The $\alpha$-tocopherol equivalent (TE) values of raw and heat treated goat milk samples are presented in Table 1. Although the values of TE were obtained slightly higher in heated milks, they were statistically insignificant $(\mathrm{P}>0.05)$. It can be said that Vitamin $\mathrm{E}$ was not affected by heating [5]. The values obtained are similar to the value $0.31 \mathrm{mg} / \mathrm{kg}$ in May and higher than the value $0.19 \mathrm{mg} / \mathrm{kg}$ in April in Saanen goat milks, as reported by Michlová et al [22].

The values of Vitamin $B_{1}$ of the samples are shown in Table 1. Heated samples LP and HP had lower amount of vitamin $\mathrm{B} 1$ than $\mathrm{R}$ samples; however, this was not statistically different $(\mathrm{P}>0.05)$, which is normally affected by heating the milk [5]. The values obtained are close to the highest Vitamin $B_{1}$ value for goat milk given by Muehlhoff et al. [43].

Vitamin B2 values of the raw and heated goat milk samples were $0.99,1.17$ (LP) and 1.07 (HP) $\mathrm{mg} / \mathrm{L}$, respectively (Table 1). Vitamin B2 values in heated samples are higher than those of raw samples, but statistically insignificant $(\mathrm{P}>0.05)$. The values obtained were among the values reported by Muehlhoff et al [43] for goat milk $(0.4-1.8 \mathrm{mg} / \mathrm{kg})$.

\subsection{Chemical Changes During Storage}

The changes in dry matter, protein, fat, acidity values of the milk samples heated at different temperatures and stored at $+4^{\circ} \mathrm{C}$ for 10 days in different bottles are shown in Table 2. As seen from the table, different heating norms, packaging materials and storage time had no effect $(\mathrm{P}>0.05)$ on dry matter values, except on $5^{\text {th }}$ day of storage when dry matter was found higher. $\mathrm{Li}$ and $\mathrm{Wu}$ [44] found similar results in a study of pasteurized cow milk. Fonseca et al. [45] found no significant change in dry matter of raw milk on the $1^{\text {st }}, 3^{\text {rd }}$ and $5^{\text {th }}$ days of storage (at $4{ }^{\circ} \mathrm{C}$ ).

The Packaging materials and storage time had no effect on protein values of the goat milk samples $(\mathrm{P}>0.05)$. However, heating at different temperatures affected $(\mathrm{P}<0.05)$ the protein values and lower value was obtained from HP samples, probably because of protein loss [46]. The values obtained are similar to those found by Fonseca et al [45] and $\mathrm{Li}$ and $\mathrm{Wu}$ [44].

Acidity values of goat milk samples pasteurized at different degrees of temperatures and stored in different packaging materials increased throughout storage. Statistical analyzes showed that the effects of heating methods LP and HP and storing in different packages of the goat milk samples was insignificant $(P>0.05)$ (Table 2). However, the effect of storage on acidity was significant $(P<0.05)$ on the $10^{\text {th }}$ day, resulting with increase. The increase in acidity might be associated with the increase in microbial growth over time, also the number of microorganisms destroyed by LP method is expected to be less than that of HP method. Similar results were found by Gürsel and Bozbay [47].

\subsection{Biochemical Changes During Storage}

The effects of the heating, packaging and storage time on hydroxymethylfurfural (HMF), non-enzymatic browning compounds (NEBC), and vitamins E, B1 and $\mathrm{B} 2$ values of the samples are shown in Table 3. As seen from the table, HMF values of HP samples were higher than those of LP samples, meaning that as heating temperature arises HMF values increased $(\mathrm{P}<0.05)$. In addition, HMF values increased during storage time and higher value was obtained on day 10th, but insignificant $(\mathrm{P}>0.05)$. Packaging materials had no effect on HMF values of the samples $(\mathrm{P}>0.05)$. Schamberger and Labuza [31] reported similar results.

Similarly, the NEBC values was affected by heating method and higher values were obtained from HP samples (pasteurized milk at $65^{\circ} \mathrm{C}$ for $\left.30 \mathrm{~min}\right)(\mathrm{P}<0.05)$. Also, NEBC values increased during storage time and highest value was obtained on day $10^{\mathrm{th}}$, however, difference was not significant $(\mathrm{P}>0.05)$. On the other hand, the NEBC values of goat milk samples were not affected by packaging materials $(\mathrm{P}>0.05)$. Güneşer et al. [29] reported similar results on browning compounds during storage.

The values of vitamin $\mathrm{E}$ as $\alpha$-TE did not affected by heating methods (LP and HP) and packaging materials $(\mathrm{P}>0.05)$. Also there is no change during $0^{\text {th }}$ and $5^{\text {th }}$ of the storage time $(\mathrm{P}>0.05)$, however, the value was higher on day $10^{\text {th }}(\mathrm{P}<0.05)$. Vidal-Valverde et al. [48] reported that UHT studies on cow milk showed significant reductions in 4-8 months of storage while no change in the amount of vitamin $\mathrm{E}$ detected during shorter storage periods of two months.

The differences between heating methods, packaging materials and storage time had no effect on the values of both vitamins B1 and B2. However, less amount of vitamin B2 $(1.11 \mathrm{mg} / \mathrm{L})$ was found from HP samples. Heating at high temperatures might cause loss in amount of vitamin $\mathrm{B} 2$, but it was statistically insignificant $(\mathrm{P}>0.05)$. The similar results were obtained by Scott et al. [25].

Table 2. The Changes in Chemical Properties of Goat Milk Samples During Storage $(\bar{x} \pm \mathrm{SD}, \mathbf{n}=\mathbf{2})$

\begin{tabular}{|c|c|c|c|c|}
\hline \multirow{2}{*}{ Factors } & \multicolumn{5}{|c|}{ Chemical properties (\%) } \\
\cline { 2 - 5 } & Dry Matter & Protein & Fat & Acidity \\
\hline \multicolumn{5}{|c|}{ Heating (n=12) } \\
\hline HP & $12.25 \pm 0.069^{\mathrm{a}^{*}}$ & $3.16 \pm 0.055^{\mathrm{b}}$ & $3.76 \pm 0.052^{\mathrm{a}}$ & $0.136 \pm 0.004^{\mathrm{a}}$ \\
\hline LP & $12.28 \pm 0.058^{\mathrm{a}}$ & $3.30 \pm 0.059^{\mathrm{a}}$ & $3.80 \pm 0.074^{\mathrm{a}}$ & $0.142 \pm 0.018^{\mathrm{a}}$ \\
\hline \multicolumn{5}{|c|}{ Packaging (Glass) (n=12) } \\
\hline Colored & $3.22 \pm 0.087^{\mathrm{a}}$ & $3.78 \pm 0.072^{\mathrm{a}}$ & $0.136 \pm 0.005^{\mathrm{a}}$ \\
\hline Transparent & $12.28 \pm 0.053^{\mathrm{a}}$ & $3.23 \pm 0.099^{\mathrm{a}}$ & $3.78 \pm 0.062^{\mathrm{a}}$ & $0.142 \pm 0.017^{\mathrm{a}}$ \\
\hline \multicolumn{5}{|c|}{ Storage Time (Day) (n=8) } \\
\hline 0 & $12.26 \pm 0.075^{\mathrm{a}}$ & $3.22 \pm 0.099^{\mathrm{a}}$ & $3.75 \pm 0.054^{\mathrm{a}}$ & $0.131 \pm 0.003^{\mathrm{b}}$ \\
\hline 5 & $12.26 \pm 0.029^{\mathrm{ab}}$ & $3.24 \pm 0.099^{\mathrm{a}}$ & $3.80 \pm 0.093^{\mathrm{a}}$ & $0.136 \pm 0.002^{\mathrm{b}}$ \\
\hline 10 & $12.31 \pm 0.038^{\mathrm{a}}$ & $3.22 \pm 0.086^{\mathrm{a}}$ & $3.79 \pm 0.035^{\mathrm{a}}$ & $0.150 \pm 0.018^{\mathrm{a}}$ \\
\hline
\end{tabular}

LP: pasteurized milk at $65{ }^{\circ} \mathrm{C}$ for 30 minutes, HP: pasteurized milk at $95{ }^{\circ} \mathrm{C}$ for 5 minutes, $\mathrm{n}=$ number of samples analyzed, SD: standard deviation, $*$ : Means of each factor on one column carrying different letters are statistically different from each other $(\mathrm{P}<0.05)$, all others not. 
Table 3. The Changes in Biochemical Properties of Goat Milk Samples During Storage ( $\bar{x} \pm \mathrm{SD}, \mathbf{n}=2)$

\begin{tabular}{|c|c|c|c|c|c|c|}
\hline \multirow[t]{2}{*}{ Biochemical Properties } & \multicolumn{6}{|c|}{ Biochemical Properties } \\
\hline & $\begin{array}{c}\mathrm{HMF} \\
(\mu \mathrm{mol} / \mathrm{L})\end{array}$ & $\begin{array}{l}\text { NEBC } \\
\left(\mathrm{A}_{340}\right)\end{array}$ & $\begin{array}{c}\text { Vit-E } \\
(\mathrm{mg} / \mathrm{L})\end{array}$ & $\begin{array}{l}\text { Vit-B } 1 \\
(\mathrm{mg} / \mathrm{L})\end{array}$ & $\begin{array}{c}\text { Vit-B } 2 \\
(\mathrm{mg} / \mathrm{L})\end{array}$ & $\begin{array}{c}\text { Phosphatase } \\
\text { test }\end{array}$ \\
\hline \multicolumn{7}{|c|}{ Heating $(\mathrm{n}=12)$} \\
\hline HP & $0.056 \pm 0.006^{\mathrm{a}^{*}}$ & $0.180 \pm 0.007^{\mathrm{a}}$ & $0.34 \pm 0.0370^{\mathrm{a}}$ & $1.74 \pm 0,010^{\mathrm{a}}$ & $1.11 \pm 0.065^{\mathrm{a}}$ & - \\
\hline LP & $0.033 \pm 0.004^{\mathrm{b}}$ & $0.121 \pm 0.015^{\mathrm{b}}$ & $0.33 \pm 0.0397^{\mathrm{a}}$ & $1.75 \pm 0,007^{\mathrm{a}}$ & $1.15 \pm 0.060^{\mathrm{a}}$ & - \\
\hline \multicolumn{7}{|c|}{ Packaging (Glass) (n=12) } \\
\hline Colored & $0.045 \pm 0.012^{\mathrm{a}}$ & $0.152 \pm 0.032^{\mathrm{a}}$ & $0.34 \pm 0.0398^{\mathrm{a}}$ & $1.74 \pm 0,010^{\mathrm{a}}$ & $1.14 \pm 0.062^{\mathrm{a}}$ & - \\
\hline Transparent & $0.045 \pm 0.013^{\mathrm{a}}$ & $0.150 \pm 0.034^{\mathrm{a}}$ & $0.34 \pm 0.0384^{\mathrm{a}}$ & $1.75 \pm 0,007^{\mathrm{a}}$ & $1.12 \pm 0.071^{\mathrm{a}}$ & - \\
\hline \multicolumn{7}{|c|}{ Storage Time (Day) $(n=8)$} \\
\hline 0 & $0.041 \pm 0.012^{\mathrm{a}}$ & $0.142 \pm 0.036^{\mathrm{a}}$ & $0.32 \pm 0.024^{b}$ & $1.74 \pm 0,000^{\mathrm{a}}$ & $1.12 \pm 0.088^{\mathrm{a}}$ & - \\
\hline 5 & $0.044 \pm 0.012^{\mathrm{a}}$ & $0.154 \pm 0.032^{\mathrm{a}}$ & $0.33 \pm 0.027^{\mathrm{b}}$ & $1.75 \pm 0,012^{\mathrm{a}}$ & $1.13 \pm 0.054^{\mathrm{a}}$ & - \\
\hline 10 & $0.050 \pm 0.014^{\mathrm{a}}$ & $0.155 \pm 0.031^{\mathrm{a}}$ & $0.37 \pm 0.039^{\mathrm{a}}$ & $1.75 \pm 0,005^{\mathrm{a}}$ & $1.14 \pm 0.058^{\mathrm{a}}$ & - \\
\hline
\end{tabular}

LP: pasteurized milk at $65{ }^{\circ} \mathrm{C}$ for 30 minutes, HP: pasteurized milk at $95{ }^{\circ} \mathrm{C}$ for 5 minutes, $\mathrm{n}=$ number of samples analyzed, SD: standard deviation, HMF: hydroxy methyl furfural, NEBC: nonenzymatic browning compound, *: Means of each factor on one column carrying different letters are statistically different from each other $(\mathrm{P}<0.05)$, all others not, -: negative reaction.

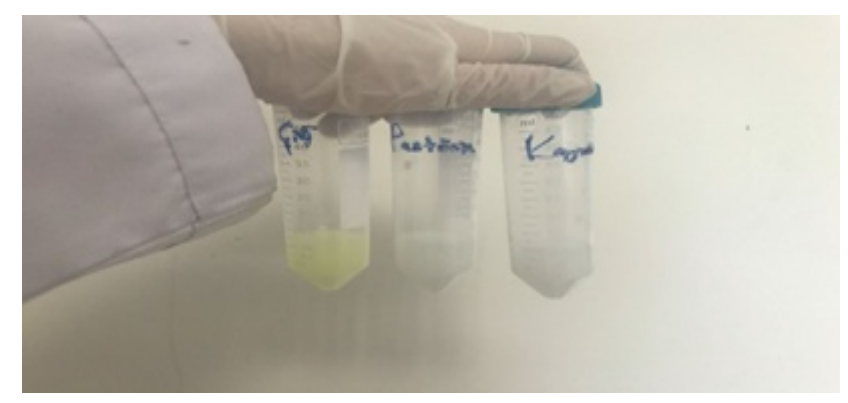

Figure 1. Color Change of Alkaline Phosphatase Enzyme Reaction (Left Tube from Raw Milk and The Right Two Tubes from Heated Milks)

Alkaline phosphatase test was performed on raw and all heated milk samples and the color changes of alkaline phosphatase enzyme activity of goat milk samples are shown in Figure 1. In the Figure, the left tube shows the reaction color with raw milk and the right two tubes show the reaction color of heated samples. During storage all samples gave negative reaction for alkaline phosphatase test (see Table 3). It is known that alkaline phosphatase enzyme is only a control test to determine the adequacy of heat treatment and for this reason negative reaction was expected during storage.

\subsection{Physical Changes During Storage}

Table 4 shows the results of statistical analysis of data of the physical properties of the goat milk samples.

According to the results, there were significant differences between sedimentation values obtained from LP and HP milks, and also storage time $(\mathrm{P}<0.05)$. Higher amounts of sedimentation values were obtained from HP samples and on day $10^{\text {th }}$ of storage time, meaning that higher temperature and prolonged storage time resulted with higher amount of sedimentation. However, using different packaging materials had no effect on the values of sedimentation $(\mathrm{P}>0.05)$. Storing the milk in the refrigerator causes a decrease in the amount of soluble calcium over time, resulting in the formation of residue of protein destabilization [38]. The results obtained are in agreement with those found by Ramsey and Swartzel [49] and Yaman and Coşkun [38] while they differ from the results of Wilson et al. [50].

Table 4. The Changes in Physical Properties of Goat Milk Samples During Storage $(\bar{x} \pm$ SD, $\mathbf{n}=\mathbf{2})$

\begin{tabular}{|c|c|c|c|c|c|}
\hline \multirow{3}{*}{ Factors } & \multicolumn{5}{|c|}{ Physical Properties (\%) } \\
\hline & \multirow{2}{*}{ Sedi-mentation } & \multirow{2}{*}{ Viscosity } & \multicolumn{3}{|c|}{ Color Values } \\
\hline & & & $\mathrm{L}^{*}$ & $a^{*}$ & $b^{*}$ \\
\hline \multicolumn{6}{|c|}{ Heating $(\mathrm{n}=12)$} \\
\hline HP & $0.055 \pm 0.007^{\mathrm{a}^{*}}$ & $3.74 \pm 0.960^{\mathrm{a}}$ & $82.460 \pm 0.374^{\mathrm{a}}$ & $-3.214 \pm 0.113^{\mathrm{a}}$ & $5.603 \pm 0.403^{\mathrm{a}}$ \\
\hline LP & $0.045 \pm 0.004^{\mathrm{b}}$ & $3.41 \pm 0.766^{\mathrm{a}}$ & $81.751 \pm 0.322^{\mathrm{b}}$ & $-3.240 \pm 0.145^{\mathrm{a}}$ & $5.835 \pm 0.396^{\mathrm{a}}$ \\
\hline \multicolumn{6}{|c|}{ Packaging (Glass) $(\mathrm{n}=12)$} \\
\hline Colored & $0.050 \pm 0.008^{\mathrm{a}}$ & $3.59 \pm 0.890^{\mathrm{a}}$ & $82.153 \pm 0.506^{\mathrm{a}}$ & $-3.192 \pm 0.146^{\mathrm{a}}$ & $5.708 \pm 0.342^{\mathrm{a}}$ \\
\hline Transparent & $0.050 \pm 0.006^{\mathrm{a}}$ & $3.56 \pm 0.880^{\mathrm{a}}$ & $82.058 \pm 0.506^{\mathrm{a}}$ & $-3.261 \pm 0.102^{\mathrm{a}}$ & $5.730 \pm 0.481^{\mathrm{a}}$ \\
\hline \multicolumn{6}{|c|}{ Storage Time (Day) $(\mathrm{n}=8)$} \\
\hline 0 & $0.046 \pm 0.004^{\mathrm{b}}$ & $2.50 \pm 0.094^{\mathrm{c}}$ & $82.457 \pm 0.461^{\mathrm{a}}$ & $-3.366 \pm 0.069^{b}$ & $5.947 \pm 0.357^{\mathrm{a}}$ \\
\hline 5 & $0.047 \pm 0.006^{\mathrm{ab}}$ & $3.78 \pm 0.367^{\mathrm{b}}$ & $81.997 \pm 0.440^{\mathrm{ab}}$ & $-3.178 \pm 0.090^{\mathrm{a}}$ & $5.484 \pm 0.285^{\mathrm{a}}$ \\
\hline 10 & $0.056 \pm 0.008^{\mathrm{a}}$ & $4.43 \pm 0.358^{\mathrm{a}}$ & $81.863 \pm 0.430^{\mathrm{b}}$ & $-3.136 \pm 0.078^{\mathrm{a}}$ & $5.726 \pm 0.465^{\mathrm{a}}$ \\
\hline
\end{tabular}

LP: pasteurized milk at $65^{\circ} \mathrm{C}$ for 30 minutes, HP: pasteurized milk at $95^{\circ} \mathrm{C}$ for 5 minutes, n: number of samples analyzed, SD: standard deviation, $\mathrm{L}^{*}$ : lightness $(0=$ black, $100=$ white $)$; a: green $(-)$ or red $(+)$; b: blue $(-)$ or yellow $(+), *$ : Means of each factor on one column carrying different letters are statistically different from each other $(\mathrm{P}<0.05)$, all others not. 
Table 4 also shows that the viscosity values of goat milk samples were affected by different methods of heat treatments during storage and higher value was obtained from the samples of HP, however, difference was not significant $(\mathrm{P}>0.05)$. Packaging the milks in colored and transparent glasses had no effect on viscosity values $(\mathrm{P}>0.05)$. On the contrast, as storage time was prolonged, viscosity values increased dramatically and reached the highest value on day $10^{\text {th }}(\mathrm{P}<0.05)$. This result is attributed to the thixotropy of the product as the water partially evaporates during heating and gel formation occurs during cooling and storage. The thixotropy of the whey protein solution is characterized by the fragmentation of disulfide and Van der Waals bonds, and ionic and hydrophobic interactions between protein particles [2]. It is also thought that with the increase in acidity, the clot formed by casein micelles may increase due to the water binding capacity. Yaman and Coşkun [38] observed that the viscosity values of frozen goat milk increased during storage.

The changes in color values of goat milk samples heattreated at different temperatures, packaged in different containers and stored in a refrigerator at $+4{ }^{\circ} \mathrm{C}$ for ten days are shown in Table 5. As in can be understand from the table, HP milk samples had higher L* (lightness) value than LP samples $(\mathrm{P}<0.05)$. In addition, The $\mathrm{L}^{*}$ values of the samples tend to decrease during storage and lower value was obtained from day $10^{\text {th }}(\mathrm{P}<0.05)$. The packaging materials did not change the $L^{*}$ values of the samples $(\mathrm{P}>0.05)$. In terms of $\mathrm{a}^{*}$ (green-red) values, they were not affected by ether heat treatments nor packaging materials $(\mathrm{P}>0.05)$, however, storage time lowered the $\mathrm{a}^{*}$ values $\left(\mathrm{P}<0.05\right.$. The values of $\mathrm{b}^{*}$ (blue-yellow) did not change significantly by heating with different methods, packaging materials and storage time $(\mathrm{P}>0.05)$. The change in the $\mathrm{L}$ * value of the samples may be due to changes in the fat and protein structure during storage [50,51]. Also, degradation of vitamin A can cause a decrease in $L^{*}$ value, while degradation of $\beta$-corotene can cause a decrease in $b^{*}$ value. The results obtained are similar to those of reported by Popov-Raljic et al. [42] and Akbulut Pinar [52].

\section{Conclusion}

In this study, the changes in some characteristics of goat milk samples heated at different temperatures and stored at $+4{ }^{\circ} \mathrm{C}$ for ten days in transparent and colored bottles were investigated. According to the results obtained; the heating affected the values of dry matter, sedimentation, $\mathrm{L}^{*}, \mathrm{a}^{*}, \mathrm{HMF}$ and NEBC of the goat milk samples $(\mathrm{P}<0.05)$ when compared with those of raw goat milk samples. In addition, storing the milk samples in colored and transparent bottles did not create any changes on the characteristics analyzed. Heating at different temperatures affected $(\mathrm{P}<0.05)$ the protein values and lower value was obtained from HP samples during storage. Acidity values of goat milk samples increased throughout storage $(P<0.05)$. HMF and NEBC values of HP samples were higher than those of LP samples $(\mathrm{P}<0.05)$, also, higher HMF and NEBC value was obtained on day $10^{\text {th }}$ of the storage. The different heating methods, packaging materials and storage time had no effect on the values of vitamins E, B1, B2. However, less amount of vitamin B2 $(1.11 \mathrm{mg} / \mathrm{L})$ was found from HP samples. During storage all samples gave negative reaction for alkaline phosphatase test. Higher heating temperature (HP) and storage time resulted with higher amount of sedimentation $(\mathrm{P}<0.05)$. As storage time was prolonged, viscosity values increased dramatically and reached the highest value on day $10^{\text {th }}$ $(\mathrm{P}<0.05)$. HP milk samples had higher $\mathrm{L}^{*}$ (lightness) values than $\mathrm{LP}$ samples $(\mathrm{P}<0.05)$. In addition, The $\mathrm{L}^{*}$ values of the samples tend to decrease during storage. Storage time lowered $\mathrm{a}^{*}$ values significantly $(\mathrm{P}<0.05)$.

\section{Acknowledgements}

This study was supported by Bolu Abant İzzet Baysal University, Scientific Research Projects Coordination Unit (Project No: 2017.09.04.1127).

\section{References}

[1] Ataşoğlu, C., Uysal-Pala, Ç. and Karagül-Yüceer, Y., "Changes in milk fatty acid composition of goats during lactation in a semi-intensive production system", Archiv Tierzucht, 6. 627-636. 2009.

[2] Gomes, J.J.L., Duarte, A.M., Batista, A.S.M., Figueiredo, R.M.F., Sousa, E.P., Souza, E.L. and Queiroga, R.C.R., "Physicochemical and sensory properties of fermented dairy beverages made with goat's milk, cow's milk and a mixture of the two milks", LWT - Food Science and Technology, 54. 18-24. 2013.

[3] Domagala, J., "Instrumental texture, syneresis and microstructure of yoghurts prepared from goat, cow and sheep milk" International Journal of Food Properties, 12. 605-615. 2009.

[4] Küçükçetin, A., Demir, M., Asçi, A. and Çomak, E.M., "Graininess and roughness of stirred yoghurt made with goat's, cow's or a mixture of goat's and cow's milk", Small Ruminant Research, 96. 173-177. 2011.

[5] Metin, M., Süt teknolojisi sütün bileşimi ve işlenmesi. Ege Üniversitesi Basımevi, Bornova, Türkiye, 2014.

[6] Demirci, M., Şimşek, O., Süt İşleme Teknolojisi. Hasad Yayıncılık İstanbul, Türkiye, 1997.

[7] Lewis, M.J., Improvements in the Pasteurisation and Sterilisation of Milk, In: Dairy Processing Improving Quality, Smit G (chief ed), Woodhead Publishing, CRC Press, Boca Raton, USA, 2003.

[8] Vassila, E., Badekaa, A., Kondylib, E., Savvaidisa, I. and Kontominasa, M.G., "Chemical and microbiological changes in fluid milk as affected by packaging conditions", International Dairy Journal, 12. 715-722. 2002.

[9] Moyssiadi, T., Badekaa, A., Kondylib, E., Vakirtzic, T., Savvaidisa, I. and Kontominasa, M.G., "Effect of light transmittance and oxygen permeability of various packaging materials on keeping quality of low fat pasteurized milk: chemical and sensorial aspects" International Dairy Journal, 14. 429-436. 2004.

[10] Khan, I.T., Nadeem, M., Imran, M., Ayaz, M., Ajmal, M., Ellahi, M.Y. and Khalique, A., "Antioxidant capacity and fatty acids characterization of heat treated cow and buffalo milk" Lipids in Health and Disease, 16. 163. 2017.

[11] Akyüz, N., "İnek sütünde vitamin A seviyesine yemin, mevsim ve coğrafik bölgenin, 1rkın, laktasyonunun elektromanyetik radyasyonun ısının ve depolamanın tesiri", Atatürk Üniversitesi Ziraat Fakültesi Dergisi, 4(7). 181-191. 1976.

[12] Asadullah, K.N., Tarar, O.M., Ali, S.A., Jamil, K. and Begum, A., "Study to evaluate the impact of heat treatment on water soluble vitamins in milk", J. Pak. Med. Assoc., 60. 909-912. 2010.

[13] Bayoumi, E.S., Abbau von thiamin wahrend des ultrahocherhitzens von vollmich, dissertation christian. AlbrechtsUniversitgt, Kiel, 1981.

[14] Bayoumi, E.S. and Reuter, H., "Destruction of vitamin $B_{1}$ during uht treatment of milk", Milchwissenschaft, 35(5). 278-279. 1980. 
[15] Görner, F. and Uherova, R., "Vitamin changes in ultra-high temperature sterilised milk during storage", Nahrung, 24(4/5). 373-379. 1980

[16] Haddad, G.S. and Loewenstein, M., "Effect of several heat treatments and frozen storage on thiamine, riboflavin, and ascorbic acid content of milk", Journal of Dairy Science, 66(8). 1601-1606. 1983.

[17] Horak, F.P. and Kessler, H.G., "Die farbmessung ais indikator hitzebehandelter lebensmittel am beispiel von milchprodukten", $Z$ Lebensm Technol Verfahrenstech, 32. 180-184. 1981.

[18] Kisza, J., Batura, K., Kruk, A. (1966). Int. Milohw., Kongr., EIF, 91.

[19] Kwok, K., Shiu, Y., Yeung, C.H. and Niranjan, K., "Effect of thermal processing on available lysine, thiamine and riboflavin content in soymilk" Journal of the Science of Food and Agriculture, 77. 478-478. 1998.

[20] Lechner, E. and Kiermeier, F., "Ascorbic acid and dehydroascorbic acid content of milk", Zeitschrift für Lebensmittel-Untersuchung und-Forschung, 141. 23-29. 1969.

[21] MacDonald, L.E., Brett, J., Kelton, D, Majowıcz, S.E, Snedeker, K. and Sargeant, J.M., "A systematic review and meta-analysis of the effects of pasteurization on milk vitamins, and evidence for raw milk consumption and other health-related outcomes", Journal of Food Protection, 74(11). 1814-1832. 2011.

[22] Michlová, T., Dragounová, H., Horníčková, S. and Hejtmánková, A., "Factors influencing the content of vitamins a and e in sheep and goat milk", Czech J. Food Science, 33(1). 58-65. 2015.

[23] Moltó-Puigmartí, C., Permanyer, M., Castellote, A.I. and LópezSabater, M.C., "Effects of pasteurisation and high-pressure processing on vitamin $\mathrm{c}$, tocopherols and fatty acids in mature human milk", Food Chemistry, 124. 697-702. 2011.

[24] Şahin, M. and Kurdal, E., "Farklı sıcaklıklarda pastörize edilen sütlerde thiamin ve riboflavin değişimi üzerine bir araştırma", Glda ve Yem Bilimi-Teknolojisi, 2. 27-30. 2002.

[25] Scott, K.J., Bishop, D.R., Zechalko, A. and Edwards-Webb, J.D., "Nutrient content of liquid milk: II. content of vitamin C, riboflavin, folic acid, thiamin, vitamins $\mathrm{B}_{12}$ and $\mathrm{B}_{6}$ in pasteurized milk as delivered to the home and after storage in the domestic refrigerator", Journal of Dairy Research, 51(1). 51-57. 1984.

[26] Sierra, I. and Vidal-Valverde, C., "Vitamin $\mathrm{B}_{1}$ and $\mathrm{B}_{6}$ retention in milk after continuous-flow microwave and conventional heating at high temperatures", Journal of Food Protection, 64(6). 890-894. 2001.

[27] Walstra, P., Wouters, J.T.M., Geurts, T.J., Dairy Science and technology, 2nd ed. Taylor and Francis, Boca Raton, FL, 2006.

[28] Zoeren-Grobben, D.V.,Schrijver, J., Van Den Berg, H. and Berger, H.M., "Human milk vitamin content after pasteurisation, storage, or tube feding", Archives of Disease in Childhood, 62. 161-165. 1987.

[29] Güneșer, O. and Karagul-Yuceer, Y., "Effect of ultraviolet light on water- and fat-soluble vitamins in cow and goat milk", Journal of Dairy Science, 11(95). 6230-6241. 2012.

[30] Morales, F.J. and Jiménez-Pérez, S., "HMF formation during heat treatment of milk-type products as related to milkfat content", Journal of Food Science, 64(5). 855-859. 1999.

[31] Schamberger, G.P. and Labuza, T.P., "Evaluation of front - face fluorescence for assessing thermal processing of milk", Journal of Food Science, 71(2). C69-C74. 2006.

[32] Metin, M., Süt ve mamülleri analiz yöntemleri. Ege Üniversitesi Mühendislik Fakültesi Yayınları, İzmir, 2008.

[33] Katsiari, M.S., Voutsinas, L.P. and Kondyli, E., "Manufacture of yoghurt from stored frozen sheep's milk" Food Chemistry, 77(4). 413-420. 2002

[34] Guingamp, M.F., Humbert, G., Midon, P., Nicolas, M. and Linden, $\mathrm{G}$. "Screening procedure for evaluating beat load in commercial milks", Elsevier, 79. 457-463. 1999.

[35] Sanchez-Machado, D.I., Lopez-Hernandez, J. and Paseiro-Losada, P., "High performance liquid chromatographic determination of $\alpha$-tocopherol in macroalgae", J. Chromatogr,. 976. 277-284. 2002.

[36] Albala-Hurtado, S., Veciana-Nogues, M.T., Izquierdo-Pulido, M. and Vidal-Carou, M.C., "Determination of free and total furfural compounds in infant milk formulas by high-performance liquid chromatography", J. Agric. Food Chem., 45. 2121-2133. 1997.
[37] Tumerman, L., Fram, H. and Cornely, K.W., "The effect of lactose crystallization on protein stability in frozen concentrated milk", Journal of Dairy Science, 37(7). 830-839. 1954.

[38] Yaman, H. and Coşkun, H., "Optimization of production technology of kes for pasta", Indian J Dairy Sci., 70 (2). 167-177. 2017.

[39] El-Hatmi, H., Jrad, Z., Salhi, I., Aguibi, A., Nadri, A. and Khorchani, T., "Comparison of composition and whey protein fractions of human, camel, donkey, goat and cow milk" Mljekarstvo, 65(3). 159-167.2015.

[40] Walstra, P., Geurts, T.J., Noomen, A., Jellema, A., Van Boekel, M.A.J.S., Dairy technology, Marcel Dekkel, New York, ABD, 1999.

[41] Güler, Z. and Park, Y.W., "Evaluation of chemical and color index characteristics of goat milk, its yoghurt and salted yoghurt", Tropical and Subtropical Agroecosystems, 11. 37 - 39. 2009.

[42] Popov-Raljić, J.V., Lakić, N.S., Laličić-Petronijević, J.G., Barać, M.B. and Sikimić, V.M., "Color changes of uht milk during storage", Sensors, 8(9). 5961-5974. 2008.

[43] Muehlhoff, E., Bennet, A., McMahon, D., Milk and dairy products in human nutrition. Food and Agricultural Organisation of the United Nations, Rome, 2013.

[44] Li, D. and Wu, D., "Effect of storage temperature on the quality of glass bottled pasteurized whole milk", Agricultural Science \& Technology, 18(5). 948-951. 2017.

[45] Fonseca, C.R., Bordin, K., Fernandes, A.M., Rodrigues, C.E.C., Corassin, C.H., Cruz, A.G. and Oliveira, C.A.F., "Storage of refrigerated raw goat milk affecting the quality of whole milk powder", J. Dairy Sci., 96. 4716-4724. 2013.

[46] Kilshaw, P.J., Heppell, L.M.J. and Ford, J.E., "Effects of heat treatment of cows' milk and whey on the nutritional quality and antigenic properties", Archives of Disease in Childhood, 57. 842847. 1982.

[47] Gürsel, A. and Bozbay, E., "Keçi sütünün farklı yöntemlerle muhafazası", Glda, 26(3). 209-220. 2001.

[48] Vidal-Valverde, C., Ruiz, R. and Medrano, A., "Effects of frozen and other storage conditions on $\alpha$ tocopherol content of cow milk", Journal of Dairy Science, 76(6). 1520-1525. 1993.

[49] Ramsey, J.A. and Swartzel, K.R., "Effect of ultra high temperature processing and storage conditions on rates of sedimentation and fat separation of aseptically packaged milk", Journal of Food Science, 49. 257-262. 1984.

[50] Winder, W.C., "Physical-chemical stability of frozen whole and concentrated milks", Journal of Dairy Science, 45(8). 1024-1027. 1962.

[51] Doan, F.J. and Baldwin, F.B., "Observations on the freezing of milk and cream II. the destruction of the fat emulsion in frozen cream", Journal of Dairy Science, 19(4). 225-233. 1936.

[52] Akbulut Pınar, B., UHT sütün yağ içeriği ve depolama sıcaklı̆̆ının maillard tepkime kinetiği üzerine etkisi, Ankara Üniversitesi Fen Bilimleri Enstitüsü Gıda Mühendisliği Anabilim Dalı Doktora Tezi, Ankara, Türkiye, 2009.

[53] Brands, C.M.J. and Van Boekel, M.A.J.S., "Reactions of monosaccharides during heating of sugar-casein systems: building of a reaction network model", Journal of Agricultural and Food Chemistry, 49 (10). 4667-4675. 2001.

[54] Engin, B., Güneşer, O. and Karagül Yüceer, Y., "Ultraviyole ışınlarının sütün mikrobiyal özellikleri üzerine etkisi", Glda, 34 (5). 303-308. 2009.

[55] Keeney, M. and Bassette, R., "Detection of intermediate compounds in the early stages of browning reaction in milk products", Journal of Dairy Science, 42(6). 945-960. 1959.

[56] Saffert, A., Pieper, G. and Jetten, J., "Effect of package light transmittance on the vitamin content of pasteurized whole milk", Packaging Technology and Science, 19(4). 211-218. 2006.

[57] Tremonte, P., Tipaldi, L., Succi, M., Pannella, G., Falasca, L., Capilongo, V., Coppola, R. and Sorrentino, E., "Raw milk from vending machines: effects of boiling, microwave treatment, and refrigeration on microbiological quality", J Dairy Sci., 97(6). 3314-20. 2014.

[58] Turgut, T., Çakmakçı, S., "Pastörize sütlerde $B_{2}$ vitamininin tahrip olması üzerine 1şı kaynağı, 1 şı şiddeti ve muhafaza süresinin etkisi", Glda, 28(5). 461-465. 2003. 